\title{
Management of Stem Rot of Groundnut (Arachis hypogea L.) using Organic Amendments and Trichoderma viride
}

\author{
P. Srujana* and Sunil Zacharia \\ Department of Plant Pathology, SHUATS, Allahabad, UP, India \\ *Corresponding author
}

A B S T R A C T

K e y w o r d s
Neem cake,
Sclerotium rolfsii,
Trichoderma viride,
Vermicompost,
Vitavax

Groundnut is a major legume and important oil seed crop belongs to family Fabaceae. A large number of diseases attack groundnut plant in India, of these stem rot caused by Sclerotium rolfsii is the most common disease. The present study was conducted in experimental field of SHUATS for management of stem rot disease of groundnut (Sclerotium rolfsii) which is most important destructive disease of groundnut in India. Therefore present studies were undertaken to test Trichoderma viride, Neem cake, vermicompost and the combinations along with the treated check (Vitavax). In in vitro conditions Trichoderma viride + Vermicompost + Neem cake significantly reduce the disease incidence of Stem rot $(15.53 \%)$ as compared to treated check with $(12.27 \%)$ and control $(54.4 \%)$ and also maximum shoot length (54.60), root length (29.47), dry weight of plants (19.47), dry weight of roots (1.53), pod yield of plants (12.16), kernel yield of plants (7.98) was observed in Trichoderma viride + Neem cake + Vermicompost. In in vivo conditions highest growth inhibition was observed in treated check (89.29\%) followed by Trichoderma viride $(60.15 \%)$ and Neem cake $(28.66 \%)$.

\section{Introduction}

Groundnut (Arachis hypogea L.) is a major legume and oilseed crop in India and in many Asian countries. In world groundnut is grown in an area of about $21.7 \mathrm{~m}$.ha with a production of 38.6 tones (FAOSTAT 2011). The productivity of groundnut crop in India is about $(1194 \mathrm{~kg} / \mathrm{ha})$ and production of 7180.5 thousand tonnes in an area of $6.8 \mathrm{~m}$.ha In Uttar Pradesh it is grown in an area of $0.85 \mathrm{~m}$.ha with a production of 65000 tones and productivity is $812 \mathrm{~kg} / \mathrm{ha}$. (Directorate of Economics and Statistics and Crops Division, DAC \& FW, India 2015-16), compared to world average (1328kg/ha) (FAO 2002).

Groundnut is called as the "King of oilseeds". It is one of the most important food and cash crops of our country. While being a valuable source of all the nutrients, it is a low priced commodity. Groundnut is also called as 
"wonder nut" and "poor men's cashew nut. Groundnut seeds are valued for oil (40-48\%) and protein $(22-26 \%)$ also contain carbohydrate (26\%) fat (3\%) and high calcium, thiamine and niacin contents, which make a substantial contribution of protein for human and animal nutrition (Maiti and Sen, 1984).Several factors are responsible for low productivity among them diseases like leaf spot, collar rot, stem rot, bud necrosis etc. are very important. Several fungal species have been reported to be associated with groundnut seed. Among the different pathogens attacking the crop, Aspergillus niger, Aspergillus flavus, Rhizoctonia bataticola and Sclerotium rolfsii are the most important fungi causing seed and seedling rots and stem rot diseases. Among the soil-borne fungal diseases, stem rot caused by Sclerotium rolfsii is a potential threat to successful groundnut cultivation.

The disease is distributed through out the world and prevalent particularly in warm dry climates. It was first reported by Clintock(1917) in Virginia. The loss of yield caused by the pathogen is $25 \%$, but sometimes it reaches to $80-90 \%$ (Grichar and Bosweel, 1987). Adiver (2003) reported the yield loss of $15-70 \%$ in groundnut is due to leaf spot, rust and stem rot singly or in combination. Stem rot caused by Sclerotium rolfsii survived for years by producing sclerotial bodies and causing the disease on various hosts Weber and Garett (1956). S. rolfsiiis a polyphagous soil borne facultative parasite and induces root rot over 500 species of plants (Punja, 1985). Though the fungus is seed and soil borne, soil borne inoculums is more important in causing infection and disease development.

Sclerotia may be spherical or irregular in shape and at maturity resemble the mustard seed (Barnett and Hunter, 1972). Sclerotial size was reported to be varied from $0.1 \mathrm{~mm}$ to $3.0 \mathrm{~mm}$ (Ansari and Agnihotri, 2000; Anahosur, 2001). Biological control has attained importance in modern agriculture to minimize the residual effects due to continuous and indiscriminate use of toxic chemicals for disease control.

Though chemical pesticides have played an important role in increasing groundnut production and management of root rot, their indiscriminate use for the control of pests has led to several environmental problems such as development of resistance in pests to pesticides, pesticide residues and the destruction of beneficial parasites and predators of pests. Thus other alternative disease management options were considered among which biological control appears promising. Majority of the existing bio-control agents for management of soil-borne diseases, were isolated from the rhizosphere. Trichoderma have been used as effective biocontrol agents against soil-borne, foliar and postharvest phytopathogenic fungal pathogens in several plant crops (Kubiceket al., 2001; Sharma et al., 2001) including groundnut (Podile and Kishore, 2002). These fungi may also promote plant growth (Inbaret al., 1994) and have the ability to colonize root surfaces and the cortex (Kleifeld and Chet, 1992).

Trichoderma spp.are widely used in agriculture as bio-pesticides, bio-protectants, bio-stimulants, and bio-fertilizers on a wide variety of plants (Harman and Kubicek, 1998). Addition of organic amendments to soil exerted favorable effect on disease reduction due to its suppressive nature (Adiver, 2003).

The organic amendments not only increase the activity of bio-control agents but also acts as source of nutrients to crop plant.

\section{Materials and Methods}

For isolating and culturing of pathogen (Sclerotium rolfsii) Potato Dextrose Agar (PDA) medium was used. 


\section{Isolation and identification of pathogen}

Small pieces of tissues about $3 \mathrm{~mm}$ from infected collar region with some healthy tissue where cut with sterile scalpel. Then the pieces surface sterilized with $1 \%$ sodium hypochlorite solution for $30 \mathrm{sec}$. The tissue pieces were subsequently washed in three changes of sterile distilled water to eliminate excess sodium hypochlorite and then pieces were transferred to PDA plated petri dishes plates were incubated at $28 \pm 2^{\circ} \mathrm{C}$ and were observed periodically for growth of the fungus. The culture was purified by single hyphal tip method. The pathogen was identified as Sclerotium rolfsii based on its mycelia and sclerotial characters (Barnett and Hunter, 1972).

\section{Dual culture technique}

$20 \mathrm{ml}$ of sterilized PDA was plated in $9 \mathrm{~cm}$ petri plates and allowed to solidify. Mycelial discs of $5 \mathrm{~mm}$ diameter of the antagonists as well as the test pathogen were cut with sterile cork borer from the periphery of an actively growing three day old culture and then placed on opposite sides of petri plate. The distance between inoculums blocks was $7 \mathrm{~cm}$.

The inoculated petri plates were incubated at $28 \pm 2^{0} \mathrm{C}$ for three days. The petri plates isolated with pathogen alone served as control. Three replications were maintained per treatment. The percent reduction in radial growth and sclerotial population of the test pathogen was calculated by using the following formula.

$I=\frac{R_{1-} R_{2}}{R_{1}} \times 100$

Where,

R1, Radial growth of Sclerotium colony in control plate;
R2, Radial growth of Sclerotium colony in dual culture plate

\section{Poisoned food technique}

Five $\mathrm{mm}$ diameter of culture disc of Sclerotium rolfsii was kept at the center of each petri plate containing the fungicides of required concentration dissolved in PDA Three replications were maintained. The plates were incubated at $27^{\circ} \mathrm{C}$ for ten days and colony diameter was recorded. Per cent inhibition of mycelial growth was calculated by using the formula given by Vincent (1947).

$I=\frac{C-T}{C} \times 100$

Where

$\mathrm{C}=$ Mycelial growth in control.

$\mathrm{T}=$ Mycelial growth in treatment.

\section{In vivo analysis}

Disease incidence percentage $(\%)$ recorded.

Observation on disease incidence recorded for a period of 30, 60 and 90 days after transplanting (Wheeler, 1969).

$$
\begin{aligned}
& \text { Disease Incidence }(\%) \\
& =\frac{\text { Total number of infected plants }}{\text { Total number of plants }} \times 100
\end{aligned}
$$

\section{Results and Discussion}

In vitro evaluation is done by dual culture and poisoned food technique and the data on the mycelial growth influenced by bio-agent are presented in below table. Minimum average radial growth of Trichoderma viride against Sclerotium rolfsii was observed in $\mathrm{T}_{1}$ Trichoderma viride $(34.03 \mathrm{~mm})$ as compared to $\mathrm{T}_{0}$ control $(85.40 \mathrm{~mm})$. 
In vitro effect of Neem cake and Vitavax on mycelial growth (mm) of Sclerotium rolfsii.

The least radial growth of Sclerotium rolfsii was observed in $\mathrm{T}_{7}$ Vitavax $(9.11 \mathrm{~mm})$ followed by $\mathrm{T}_{3}$ Neem cake $(60.71 \mathrm{~mm})$ as compared to control $\mathrm{T}_{0}$ Control $(85.10 \mathrm{~mm})$. The similar findings is reported by Saralamma and Vittal Reddy (2003)where they notice combined application of bio agent, fungicide and neem cake effectively suppressed Sclerotium rolfsii, the incitant of stem rot in groundnut. Varadarajan karthikeyan, Ambalavanan (2006) also reported that Trichoderma viride is most effective in suppressing sclerotial formation. Among the organic amendments tested mahua cake with Trichoderma viride each @ 5g/kg of soil resulted in $3.75 \%$ stem rot incidence as against $39.98 \%$ in control. Palaiahet al.,(2007) also reported that using more than one type of bioagent for the management of Sclerotium rolfsii in addition to using both chemical and bio agent tools for its better management. Similar findings were reported by Saralamma and Vittal Reddy (2003) also that combined application of pathogen + bio-agent + fungicide + neem cake gave higher yield of $863 \mathrm{~kg} / \mathrm{ha}$ over control $(224 \mathrm{~kg} / \mathrm{ha})$ respectively.

Table.1 Details of the Treatments

\begin{tabular}{|c|c|}
\hline TREATMENTS & CONCENTRATION \\
\hline $\mathbf{T}_{\mathbf{0}}$-Control & - \\
\hline $\mathbf{T}_{\mathbf{1}}$-Trichodema viride & $1.5 \mathrm{~g} / \mathrm{kg}$ \\
\hline $\mathbf{T}_{\mathbf{2} \text { - vermicompost }}$ & $10 \mathrm{tonnes} / \mathrm{ha}$ \\
\hline $\mathbf{T}_{\mathbf{3}}$-Neem cake & $500 \mathrm{~kg} / \mathrm{ha}$ \\
\hline $\mathbf{T}_{\mathbf{4}}$-Trichodema viride+vermicompost & $1.5 \mathrm{~g} / \mathrm{kg}+10 \mathrm{tonnes} / \mathrm{ha}$ \\
\hline $\mathbf{T}_{\mathbf{5}}$-Trichodema viride+Neem cake & $1.5 \mathrm{~g} / \mathrm{kg}+500 \mathrm{~kg} / \mathrm{ha}$ \\
\hline $\mathbf{T}_{\mathbf{6}}$-Trichodemaviride+Neem cake+vermicompost & $1.5 \mathrm{~g} / \mathrm{kg}+500 \mathrm{~kg} / \mathrm{ha}+$ \\
& $10 \mathrm{tonnes} / \mathrm{ha}$ \\
\hline T7-Vitavax & $2 \mathrm{~g} / \mathrm{kg}$ \\
\hline
\end{tabular}

Table.2 Antagonistic effect of Trichoderma viride on mycelial growth (mm) of Sclerotium rolfsii.

\begin{tabular}{|c|c|c|c|c|c|c|}
\hline \multirow{2}{*}{ S.NO } & \multirow{2}{*}{ TREATMENTS } & \multicolumn{4}{|c|}{ Radial growth $(\mathbf{m m})$ of Sclerotium rolfsii } \\
\cline { 3 - 7 } & & $24 \mathrm{hrs}$ & $48 \mathrm{hrs}$ & $72 \mathrm{hrs}$ & $96 \mathrm{hrs}$ & $120 \mathrm{hrs}$ \\
\hline $\mathbf{T}_{\mathbf{1}}$ & Trichoderma viride & 11.9 & 25.2 & 28.6 & 31.8 & 34.03 \\
\hline $\mathbf{T}_{\mathbf{0}}$ & Control & 34.8 & 51.1 & 71.9 & 77.4 & 85.4 \\
\hline & F-test & $\mathrm{S}$ & $\mathrm{S}$ & $\mathrm{S}$ & $\mathrm{S}$ & $\mathrm{S}$ \\
\hline & SE.d & 0.15 & 0.26 & 0.38 & 0.31 & 0.49 \\
\hline & CD (5\%) & 0.65 & 1.12 & 1.65 & 1.36 & 2.14 \\
\hline
\end{tabular}


Table.3 In vitro effect of Neem cake and Vitavax on mycelial growth ( $\mathrm{mm}$ ) of Sclerotium rolfsii.

\begin{tabular}{|c|c|c|c|c|c|c|}
\hline \multirow{2}{*}{ S.NO } & \multirow{2}{*}{ TREATMENTS } & \multicolumn{4}{|c|}{ Radial growth $(\mathbf{m m})$ of Sclerotium rolfsii } \\
\cline { 3 - 7 } & & $24 \mathrm{hrs}$ & $48 \mathrm{hrs}$ & $72 \mathrm{hrs}$ & $96 \mathrm{hrs}$ & $120 \mathrm{hrs}$ \\
\hline $\mathbf{T}_{\mathbf{0}}$ & Control & 34.96 & 50.9 & 72.07 & 77.05 & 85.10 \\
\hline $\mathbf{T}_{\mathbf{3}}$ & Neem cake & 20.16 & 42.10 & 50.06 & 58.11 & 60.71 \\
\hline $\mathbf{T}_{\mathbf{7}}$ & Vitavax & 1.73 & 4.76 & 6.99 & 7.96 & 9.11 \\
\hline & F-test & $\mathrm{S}$ & $\mathrm{S}$ & $\mathrm{S}$ & $\mathrm{S}$ & $\mathrm{S}$ \\
\hline & SE.d & 0.24 & 0.29 & 0.32 & 0.36 & 0.37 \\
\hline & CD (5\%) & 0.67 & 0.82 & 0.89 & 1.02 & 1.03 \\
\hline
\end{tabular}

Table.4 Effect of organic amendments and Trichoderma viride on percentage of disease incidence (\%) of Sclerotium rolfsii at different DAS

\begin{tabular}{|c|c|c|c|}
\hline TREATMENTS & 60 Days & 75 Days & 90 Days \\
\hline $\mathbf{T}_{\mathbf{0}}$ & 31.10 & 44.40 & 54.4 \\
\hline $\mathbf{T}_{\mathbf{1}}$ & 14.47 & 21.10 & 28.87 \\
\hline $\mathbf{T}_{\mathbf{2}}$ & 24.40 & 36.60 & 42.27 \\
\hline $\mathbf{T}_{\mathbf{3}}$ & 21.10 & 28.90 & 34.47 \\
\hline $\mathbf{T}_{\mathbf{4}}$ & 10.00 & 16.60 & 21.10 \\
\hline $\mathbf{T}_{\mathbf{5}}$ & 7.78 & 14.40 & 18.87 \\
\hline $\mathbf{T}_{\mathbf{6}}$ & 5.56 & 11.10 & 15.53 \\
\hline $\mathbf{T}_{\mathbf{7}}$ & 4.44 & 10.00 & 12.27 \\
\hline F-test & $\mathrm{S}$ & $\mathrm{S}$ & $\mathrm{S}$ \\
\hline S.Ed. & 0.75 & 0.91 & 1.09 \\
\hline C.D. $(=\mathbf{0 . 0 5})$ & 1.61 & 1.95 & 2.35 \\
\hline
\end{tabular}

Fig.1 Sclerotial bodies on pathogen

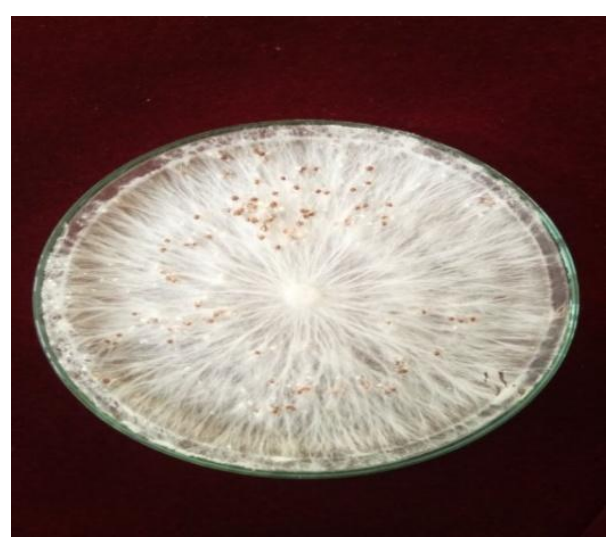

Fig.2 Microscopic view of pathogen

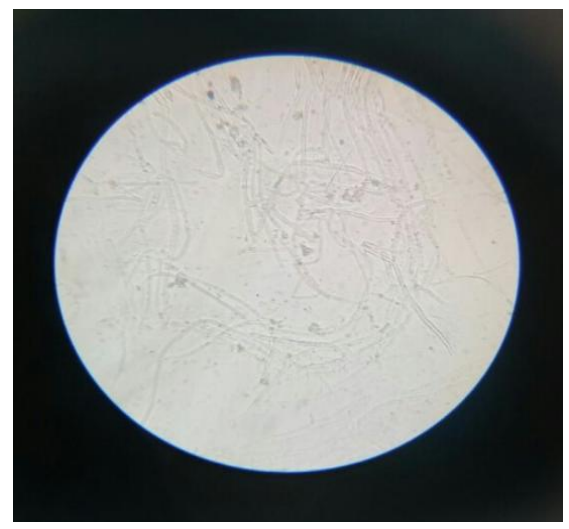


Fig.3 Antagonistic effect of Trichoderma viride against growth of Sclerotium rolfsii (Dual Culture Technique)

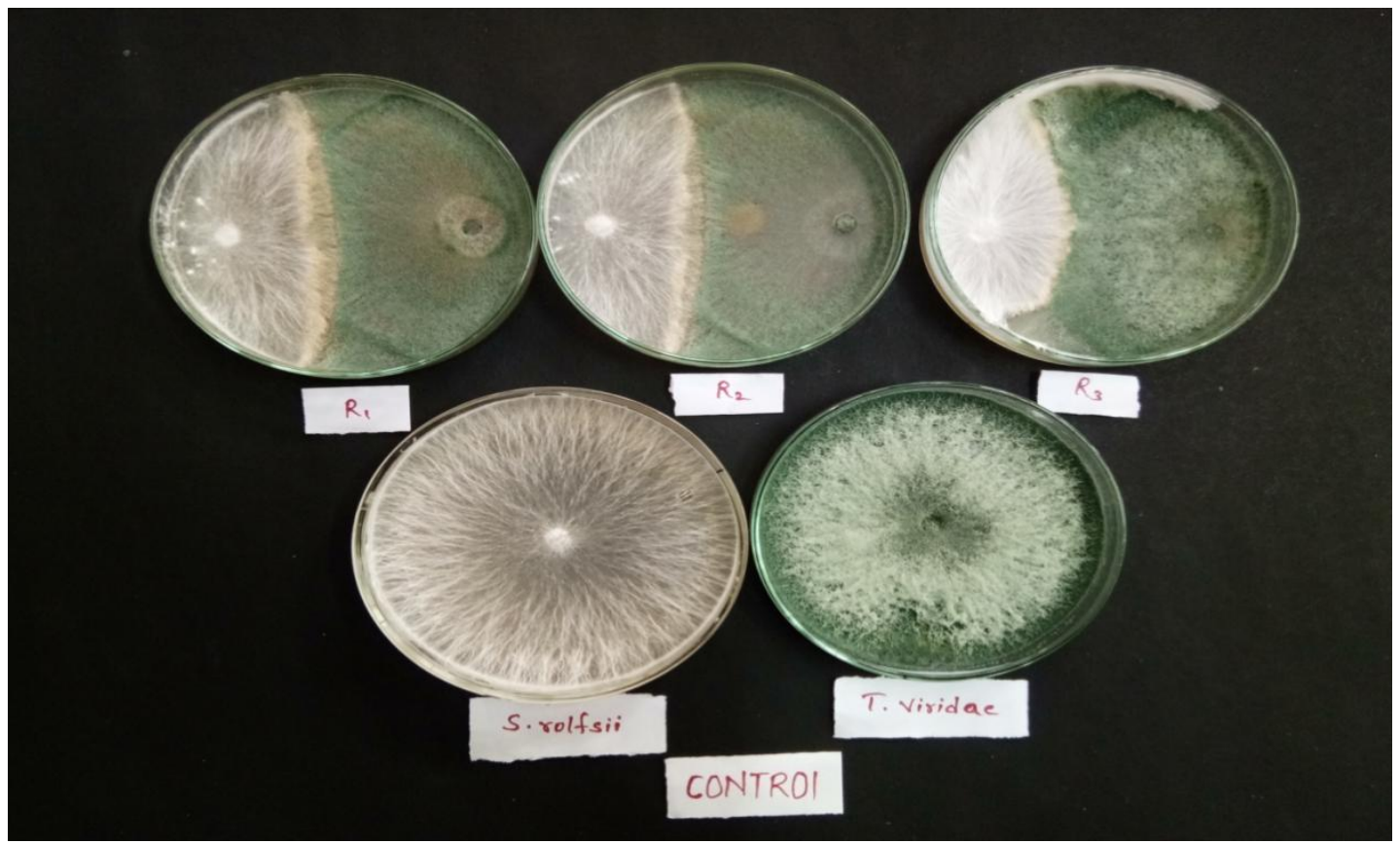

Fig.4 Poison food technique treated with vitavax Fig 4.3 Poison food technique with neem cake

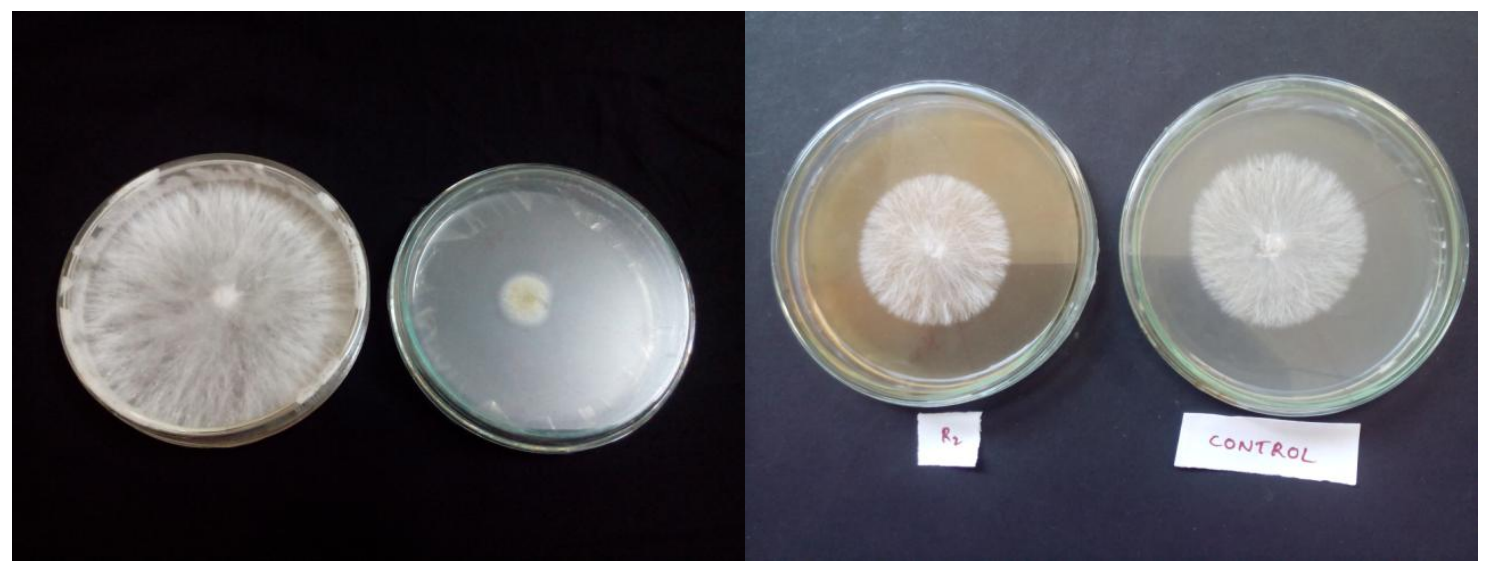


Fig.5 Graphical representation of field efficacy of treatments on the incidence of Sclerotium rolfsii (\%) of groundnut at different DAS

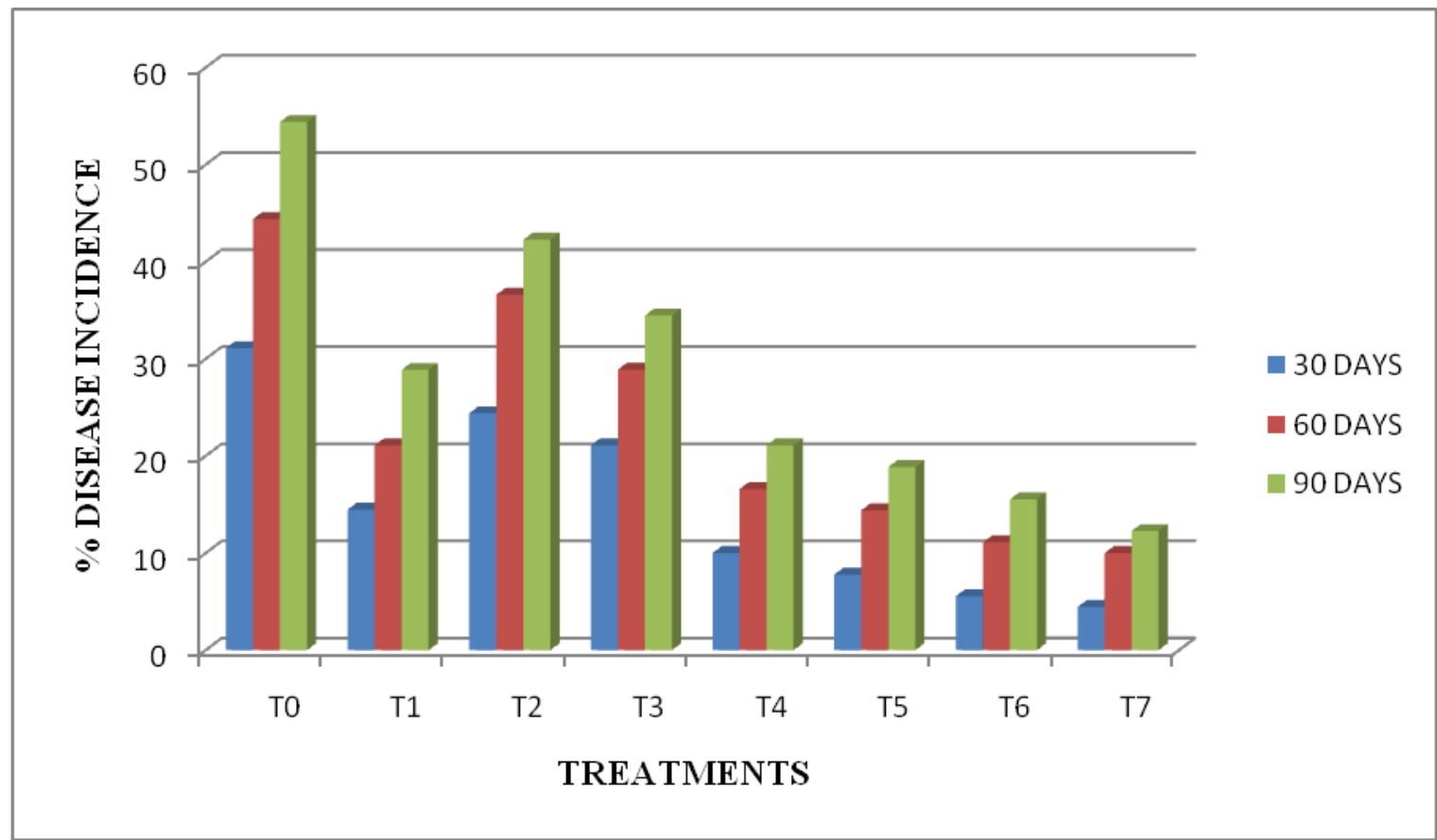

\section{References}

Adiver, S. S. (2003). Influence of organic amendments and biological component on stem rot of groundnut. ISOR, National Seminar: Stress Management in Oil Seeds, January 28-30, 15-17.

Ansari, M. M. andAgnihotri, S.K.(2000). Morphological, Physiological and Pathological Variations Among Sclerotium rolfsii Isolates of Soyabean. Indian Phytopathology.(53) : 65-67.

Asghari, M.A. and Mayee, C.D. (1991). Comparative efficacy of management practices on stem and pods rots of groundnut.

Phytopathology.44(3): 328-332.

AtlaRangaRani, (2017). Stem rot of groundnut incited by Sclerotium rolfsii Sacc. and its management $-\mathrm{A}$ review : Science and Research (IJASR).7(3).

Bagawan, N.B. (2011).Evaluation of biocontrol potential of Trichoderma species against Sclerotium rolfsii,
Aspergillusniger

Aspergillusflavus.

and Journal of Plant Protection.4(1) : 107111.

Barnett, H.H. and Hunter, B.B. (1972).Illustrated genera of imperfect fungi. Burgess Publishing Company, Minnesota.

Charitha, D. M. and Reddy, M. N. (2003). Biological control of Sclerotium rolfsii the incitant of root rot of groundnut. National seminar on Stress Management in oilseeds, ISOR, Directorate of Oil seeds Research, Hyderabad, January 28-30, pp 18-19.

Chet, I. (1975). Ultra Structural Basis of Sclerotial Survival in Soil. Microbial Ecology: 2, 194-200.

Clintock, Mc. (1917). Peanut wilt caused by Sclerotium rolfsii. Journal of Agricultural Research. 8: 441-448.

DAC and FW (2015-16) Directorate of Economics and Statistics and Crops Division, DAC \& FW, 2015-16. 
Deepthi, K.C. and Eswara Reddy, N.P. (2013).Stem rot disease of groundnut (Arachis hypogaea l.) Induced by Sclerotium rolfsii and its management, International journal of life sciences biotechnology and pharma research.2(3) : 2250-3157.

Deepthi, K.C. (2013). Effect of potential biocontrol agents against Sclerotium rolfsii causing stem rot of groundnut.2(2) : 2250-3157.

Doley, K. and Jite, P.K. (2013).Management of Stem-rot of Groundnut (Arachis hypogaea L.) Cultivar in Field Khirood. Notulae Science Biologicae.5(3):316 -324.

FAOSTAT (2002).Food And Agriculture Organisation of the United Nations, Rome, Italy, 2002.

FAO (2011).Weight percentages of food losses and waste, 2011.

Gayatri Nahak and RajaniKantaSahu (2015). Biopesticidal effect of leaf extract of neem (Azadira chtaindica A. Juss) ongrowth parameters and diseases of tomato.Journal of Applied and Natural Science. 7 (1) : $482-488$.

Gerrett, S.D. (1956). Biology of Root Infecting Fungi,p.293, Cambridge University Press, London.

Grichar, V.J. and Bosweel, T.E. (1987). "Comparison of Lorsban and Tilt With Terrachlor For Control of Southern Blight on Peanut the Texas," Agriculture Experiment Station Pr4534.

Harman, G.E. (2006). Overview of mechanisms and uses of Trichoderma spp. Phytopathology. 96: 190-194.

Inbar, J. and Chet. (1994). The role of recognition in the inductor of specific chitinases during mycoparasitism of Trichoderma harizanum. Microbiology. 141: 2823-2829.

Ingale, R.V. and Mayee, C.D. (1986).Efficacy and economics of some management practices of fungal diseases of groundnut. Journals of Oilseeds Research.(3) : 201-204.

Jegathambigai, V. (2010). Effect of Trichoderma spp. on Sclerotium rolfsii, the causative agent of collar rot on Zamioculcas zamiifolia and an on Farm method to Mass produce Trichoderma spp. Plant Pathology Journal.9(2):47-55.

Kleifeld and Chet. (1992). Trichoderma harzianum- interaction with plants and effect on growth response, plant and soil $144(2)$ : 267-272.

Kubicek, (2001).Trichoderma: From genes to bio-control, 83(2) :11-23.

Manjula, K. (2004). Combined Application of Pseudomonas fluorescens and Trichoderma viride has an Improved Bio-control Activity Against Stem Rot in Groundnut. The Korean Society of Plant Pathology, 75-80.

Mayee, C.D. andDatar, V.V.(1988).Diseases of Groundnut in the Tropics.Review of Tropical Plant Pathology. (5) 85-118.

Narendra Kumar (2013). Sclerotium stem rot: A threat to groundnut production. Popular Kheti, 1 (3) :2321-0001.

Palaiah, P., Adiveer, S. S., Kumara, O., Chandrappa, D. and Jangandi, S. (2007). Senstivity of Sclerotium rolfsiisacc. isolates to different agrochemical and cultural filtrates of bio-agents. Karnataka Journal of Agricultural Sciences. 11, 423-425.

Pandey, M.K., Sarma, B.K. and Singh, U.P. (2005). Induction of Sexual Stage and Colony Morphology of Some Isolates of Sclerotium rolfsii Causing Spotted Leaf Rot in Plants, The Korean Society of Mycology.33(1): 7-11 (2005).

Podile, A.R. and Kishore, G.K. (2002). Biological control of peanut diseases. pp. 131-160.

Pratibha Sharma, Mahesh Kumar Saini, Swati Deep and Vinesh Kumar.(2012). 
Biological Control of Groundnut Root Rot in Farmer's Field, Journal of Agricultural Science.4(8) :1916-9752.

Rakholiya, K.B.and Jadeja, K.B. (2010).Effect of soil amendments and bio-control agents for management of stem and pod rot of groundnut. International Journal of Plant Protection.3(2) : 348349.

Rakholiya, K.B. and Jadeja, K.B. (2010). Effect of seed treatment of bio-control agents and chemicals for management of stem and pod rot of groundnut. International Journal of Plant Protection.3(2) : 276-278.

Rolfs, P.H. (1892). Tomato blight-some hints. Fla. Agric. Experiment Sta. Bull, 18.

Saccardo, P.A. (1911). Notae Mycologicae, Annuals Mycologici. 9, 249-257.

Suheri, H., Isnaini, M. and Rohyadi, A. (2014). Application of organic amendment and Trichoderma spp. to control basal Sclerotium rolfsii on peanut grown on partially degraded land. Journal of degraded and mining lands management.1 (3) : 2339-076, 131-136.

Varadharajan, K., Ambalavanan, S. and Sevugaperumal, N. (2004). Management of groundnut root rot with bio-control agents and organic amendments, Archives of Phytopathology and Plant Protection. 39(3): 215-223.

Varadharajan, K., Ambalavanan,S. and Sevugaperumal, N. (2005). Biological control of groundnut stem rot caused by Sclerotium rolfsii (Sacc.) Archives of Phytopathology and Plant Protection. 39(3): 239-246.

Weber and Garrett, S.D. (1956).Biology of Root Infecting Fungi, Cambridge University Press, New York.

\section{How to cite this article:}

Srujana, P. and Sunil Zacharia. 2020. Management of Stem Rot of Groundnut (Arachis hypogea L.) using Organic Amendments and Trichoderma viride. Int.J.Curr.Microbiol.App.Sci. 9(01): 62-70. doi: https://doi.org/10.20546/ijcmas.2020.901.007 